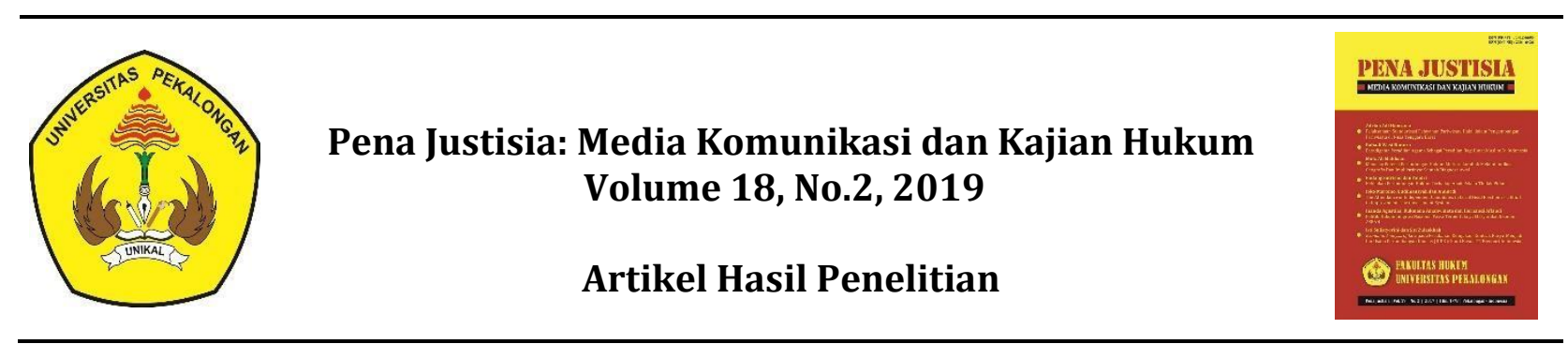

\title{
EFEKTIVITAS PENERAPAN SANKSI PIDANA PENJARA TERHADAP ANAK YANG MELAKUKAN TINDAK PIDANA
}

\author{
Nurika Latiff Hikmawati
}

** Fakultas Hukum Universitas Jenderal Soedirman

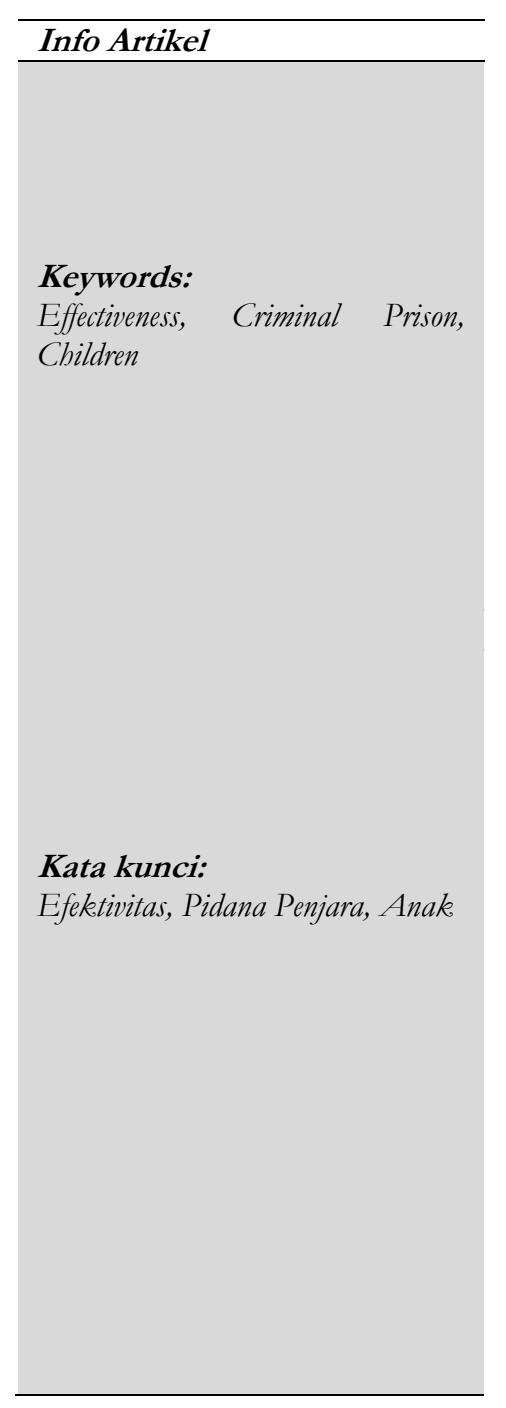

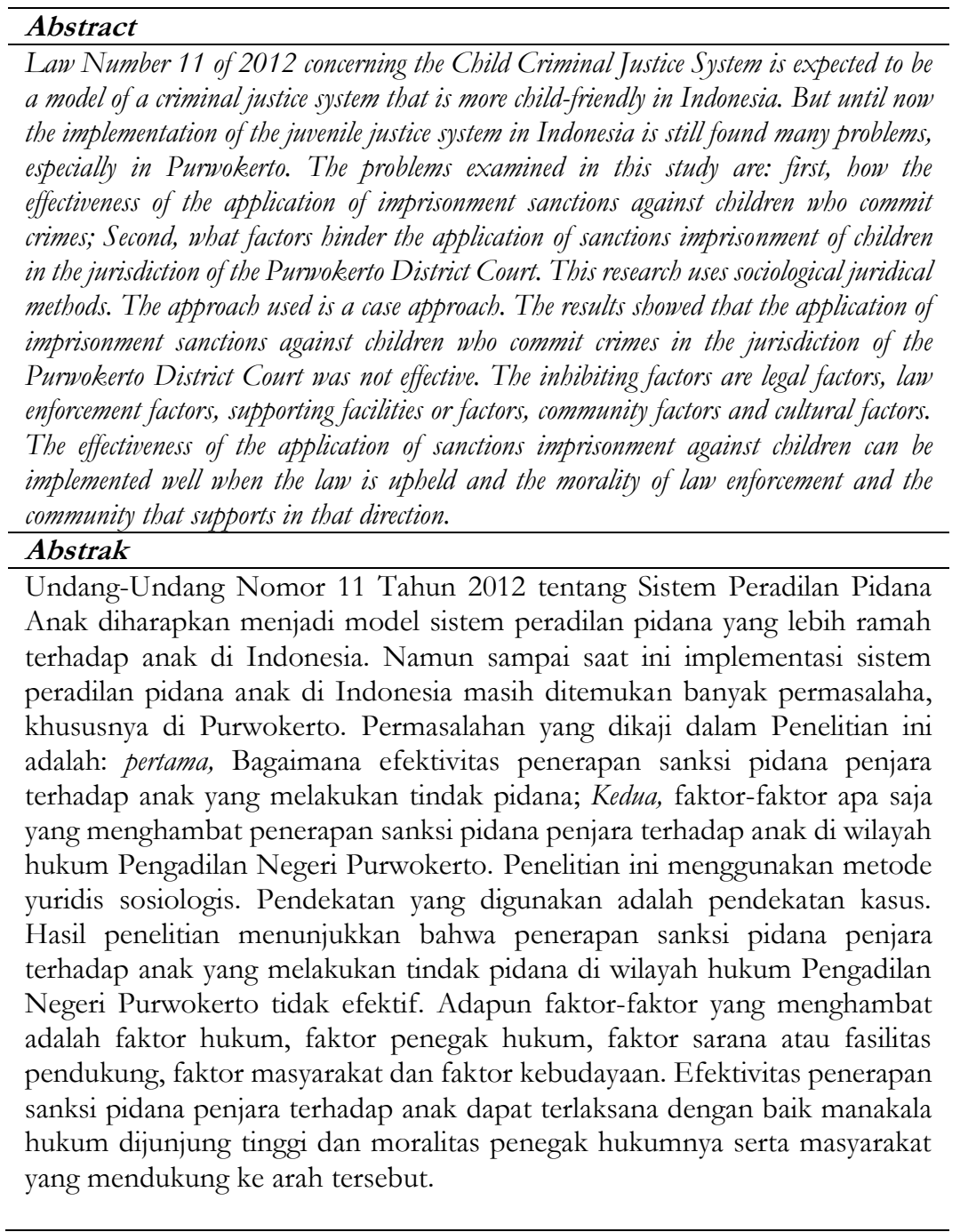

\section{PENDAHULUAN}

Saat ini banyak dijumpai anak-anak yang berperilaku menyimpang. Perilaku menyimpang anak semakin tampak jelas di tengah-tengah masyarakat. Kenyataan ini menunjukkan bahwa perilaku 
mereka sudah sangat mengkhawatirkan dan merupakan masalah yang berbahaya. Hal ini disebabkan oleh berbagai faktor antara lain adanya dampak negatif dari arus globalalisasi, komunikasi, informasi, kemajuan ilmu pengetahuan dan teknologi, dan perubahan gaya hidup telah membawa perubahan sosial yang mendasar dalam kehidupan masyarakat, terlebih kepada perilaku anak.

Kenakalan anak sudah tidak bisa dipandang lagi sebagai kenakalan biasa, anak-anak banyak melakukan perbuatan yang tergolong tindak pidana. Namun demikian, anak yang melakukan tindak pidana dan perbuatan yang dilarang oleh hukum, harus ditafsirkan sebagai ketidakmampuan akal (pikiran), fisik (badan) atau moral dan mentalitas yang ada pada diri anak yang ditentukan oleh nilai kodrat. ${ }^{1}$

Berdasarkan Sistem Informasi Penelusuran Perkara pada Pengadilan Negeri Purwokerto menunjukan bahwa, dalam kurun waktu tahun 2014 sampai tahun 2017 terdapat 39 perkara anak dan 25 diantaranya dikenakan sanksi pidana penjara oleh hakim. ${ }^{2}$ Banyaknya putusan Pengadilan Negeri Purwokerto yang cenderung menjatuhkan pidana penjara daripada tindakan terhadap anak, sebenarnya tidak sesuai dengan filosofi dari pemidanaan dalam hukum pidana anak. Penjatuhan pidana secara tidak tepat dapat mengabaikan pengaturan perlindungan, karena pemidanaan anak seharusnya adalah jalan keluar terakhir (ultimum remedium/the last resort principle) dan dijatuhkannya hanya untuk waktu yang singkat. Penjatuhan pidana sebagai ultimum remedium atau the last resort principle adalah salah satu bentuk perlindungan terhadap kepentingan terbaik anak. ${ }^{3}$

Perlindungan hukum terhadap anak adalah segala kegiatan untuk menjamin dan melindungi anak dan hak-haknya agar tetap hidup, tumbuh, berkembang dan berpartisipasi secara optimal sesuai dengan harkat dan martabat kemanusiaan, serta mendapat perlindungan dari kekerasan dan diskriminasi. Perlindungan dan jaminan kepastian hukum diberikan oleh Undang-Undang Nomor 35 Tahun 2014 tentang Perlindungan Anak harus mempertimbangkan kepentingan terbaik anak. Dalam menangani kasus anak yang berhadapan dengan hukum harus bertumpu pada ketentuanketentuan dalam Undang-Undang Nomor 11 Tahun 2012 tentang Sistem Peradilan Pidana Anak.

Undang-Undang Nomor 11 Tahun 2012 tentang Sistem Peradilan Pidana Anak (UU SPPA) diharapkan menjadi model sistem peradilan pidana yang lebih ramah terhadap anak di Indonesia. Namun sampai saat ini implementasi sistem peradilan pidana anak di Indonesia masih ditemukan permasalahan, khususnya di wilayah hukum Pengadilan Negeri Purwokerto, terkait dengan penerapan sanksi pidana penjara terhadap anak masih terdapat kendala atau hambatan dalam penerapannya. Hal ini menjadi dilema bagi anak yang berhadapan dengan hukum. Akibat dalam penerapan UU SPPA ini yang masih tersendat, maka membuat kasus hukum yang melibatkan anak belum diterapkan secara maksimal sehingga dapat menimbulkan kerugian bagi anak. Tulisan ini akan membahas dan mempertanyakan efektivitas penerapan sanksi pidana penjara terhadap anak yang melakukan tindak pidana di wilayah hukum Pengadilan Negeri Purwokerto, dan faktor-faktor penghambat efektivitas penerapan sanksi pidana penjara terhadap anak yang melakukan tindak pidana di wilayah hukum Pengadilan Negeri Purwokerto.

\section{PEMBAHASAN}

\section{Efektivitas Penerapan Sanksi Pidana Penjara Terhadap Anak Yang Melakukan Tindak Pidana Di Wilayah Hukum Pengadilan Negeri Purwokerto.}

Efektivitas dalam hal ini mengandung pengertian kegiatan yang dapat mengenai sasaran dengan tujuan atau efek dari penerapan sanksi pidana penjara terhadap anak yang melakukan tindak pidana.

Wadong, Maulana Hasan, 2000, Advokasi dan Hukum Perlindungan Anak, Jakarta: Grasindo, hlm. 68.

Pra Riset dari Sistem Informasi Penelusuran Perkara (SIPP) Pengadilan Negeri Purwokerto

Kurniawan, Riza Alfianto. “Asas Ultimum Remedium Dalam Pemidanaan Anak Nakal”. Yuridika. Vol 23 , No 1. Edisi Tahun 2008. Penerbit: Yuridika. Hlm. 3. 
Efektivitas disini menyangkut tingkat kegunaan sarana tertentu untuk mencapai suatu tujuan tertentu, sehingga efektivitas sebenarnya bukan hanya di tingkat realisasinya tujuan-tujuan tertentu saja, melainkan juga pada tingkat peran sarana yang dipilih untuk mencapai tujuan tersebut. Suatu peraturan akan menjadi efektif apabila dalam pembuatan maupun implementasinya didukung oleh sarana-sarana yang memadai. ${ }^{4}$

Anak adalah bagian yang tidak terpisahkan dari keberlangsungan hidup manusia dan keberlangsungan sebuah bangsa dan negara. Anak memiliki peran strategis yang secara tegas dalam konstitusi Indonesia dinyatakan bahwa negara menjamin hak-hak setiap anak atas kelangsungan hidup, tumbuh, dan berkembang serta atas pelindungan dari kekerasan dan diskriminasi. ${ }^{5}$ Oleh karena itu, kepentingan terbaik bagi anak patut dihayati sebagai kepentingan terbaik bagi kelangsungan hidup umat manusia. Konsekuensi dari ketentuan Pasal 28B ayat (2) Undang-Undang Dasar Negara Republik Indonesia Tahun 1945 perlu ditindaklanjuti dengan membuat kebijakan pemerintah yang bertujuan melindungi anak.

Pengertian anak menurut UU SPPA dibagi menjadi 3 (tiga) definisi anak yang berhubungan dengan tindak pidana sebagai berikut:

a. Anak yang Berkonflik dengan Hukum yang selanjutnya disebut Anak adalah anak yang telah berumur 12 (dua belas) tahun, tetapi belum berumur 18 (delapan belas) tahun yang diduga melakukan tindak pidana (Pasal 1 angka 3 UU SPPA).

b. Anak yang Menjadi Korban Tindak Pidana yang selanjutnya disebut Anak Korban adalah anak yang belum berumur 18 (delapan belas) tahun yang mengalami penderitaan fisik, mental, dan/atau kerugian ekonomi yang disebabkan oleh tindak pidana (Pasal 1 angka 4 UU SPPA).

c. Anak yang Menjadi Saksi Tindak Pidana yang selanjutnya disebut Anak Saksi adalah anak yang belum berumur 18 (delapan belas) tahun yang dapat memberikan keterangan guna kepentingan penyidikan, penuntutan, dan pemeriksaan di sidang pengadilan tentang suatu perkara pidana yang didengar, dilihat, dan/atau dialaminya sendiri (Pasal 1 angka 5 UU SPPA).

Masalah anak yang melakukan tindak pidana dapat dengan mudah dipahami, yakni melanggar pasal-pasal yang diatur dalam KUHP atau peraturan hukum pidana diluar KUHP. Pasal 71 UU SPPA menempatkan pidana penjara di dalam kelompok pidana pokok pada urutan kelima atau terakhir yakni sesudah pembinaan dalam lembaga. Ketentuan mengenai pidana penjara diatur dalam Pasal 81 UU SPPA, yaitu:

(1) Anak dijatuhi pidana penjara di LPKA apabila keadaan dan perbuatan Anak akan membahayakan masyarakat.

(2) Pidana penjara yang dapat dijatuhkan kepada Anak paling lama 1/2 (satu perdua) dari maksimum ancaman pidana penjara bagi orang dewasa.

(3) Pembinaan di LPKA dilaksanakan sampai anak berumur 18 (delapan belas) tahun.

(4) Anak yang telah menjalani $1 / 2$ (satu perdua) dari lamanya pembinaan di LPKA dan berkelakuan baik berhak mendapatkan pembebasan bersyarat.

(5) Pidana penjara terhadap Anak hanya digunakan sebagai upaya terakhir.

(6) Jika tindak pidana yang dilakukan oleh Anak merupakan tindak pidana yang diancam pidana mati atau pidana penjara seumur hidup, pidana yang dijatuhkan adalah pidana penjara paling lama 10 (sepuluh) tahun.

4 Darwan Prinst, 2003, Hukum Anak Indonesia, Bandung: PT. Citra Aditya Bakti, hlm. 36.

Lihat dalam ketentuan Pasal 28B ayat (2) UUD 1945, diatur bahwa: “setiap anak berhak atas kelangsungan hidup, tumbuh dan berkembang serta berhak atas perlindungan dari kekerasan dan diskriminasi”. Dengan demikian, anak mempunyai hak konstitusional atas perlindungan dari serangan orang lain, termasuk menjamin peraturan perundang-undangan yang pro dengan hak anak. 
Terkait dengan hal tersebut di atas, penulis mengadakan penelitian dan memperoleh hasil sebagai berikut:

Daftar Perkara Pidana Anak Di Pengadilan Negeri Purwokerto Tahun 2014-2017

\begin{tabular}{|l|l|l|l|l|l|l|}
\hline \multirow{2}{*}{ No } & \multirow{2}{*}{$\begin{array}{l}\text { Klasifikasi Tindak } \\
\text { Pidana }\end{array}$} & $\begin{array}{l}\text { Tahun } \\
2014\end{array}$ & $\begin{array}{l}\text { Tahun } \\
2015\end{array}$ & $\begin{array}{l}\text { Tahun } \\
2016\end{array}$ & $\begin{array}{l}\text { Tahun } \\
2017\end{array}$ & \multirow{2}{*}{$\begin{array}{l}\text { Jumlah } \\
\text { Total }\end{array}$} \\
\cline { 3 - 6 } & Jumlah & Jumlah & Jumlah & Jumlah & \\
\hline 1 & Pencurian & 3 & 8 & 3 & 11 & 25 \\
\hline 2 & Perlindungan Anak & 1 & 1 & 5 & 1 & 8 \\
\hline 3 & Penadahan & & 1 & & & 1 \\
\hline 4 & Penggelapan & & 1 & & & 1 \\
\hline 5 & Pengeroyokan & & & 2 & 1 & 3 \\
\hline 6 & Pemerasan & & & & 1 & 1 \\
\hline \multicolumn{2}{|l|}{ Jumlah Perkara } & 4 & 11 & 10 & 14 & 39 \\
\hline \multicolumn{2}{|l|}{ Putusan pidana penjara } & 2 & 9 & 5 & 9 & 25 \\
\hline
\end{tabular}

Sumber Data: Buku Registrasi dari Pengadilan Negeri Purwokerto, yang diolah oleh Penulis.

Pada Pengadilan Negeri Purwokerto selama tahun 2014 sampai tahun 2017 terdapat 39 perkara anak dan 25 diantaranya dikenakan sanksi pidana penjara oleh hakim. Jumlah perkara anak yang ditangani oleh Pengadilan Negeri Purwokerto hampir selalu mengalami peningkatan dari tahun ke tahun. Pada tahun 2014 terdapat 4 kasus, tahun 2015 terdapat 11 kasus, tahun 2016 mengalami sedikit penurunan yaitu terdapat 10 kasus, akan tetapi tahun 2017 meningkat kembali bahkan hingga mencapai 14 kasus. Ini menunjukan jumlah yang cukup memprihatinkan mengingat anak adalah sebagai generasi penerus bangsa.

Berdasarkan hal tersebut maka efektivitas pidana penjara dilihat dari aspek perlindungan masyarakat menunjukan bahwa, walaupun di Pengadilan Negeri Purwokerto pada tahun 2014 sampai tahun 2017 tidak ada recidivis anak, namun penerapan sanksi pidana penjara terhadap anak belum mampu menekan frekuensi kejahatan yang terjadi. Hal ini dibuktikan dengan meningkatnya kasus anak dari tahun ke tahun, sehingga pidana penjara belum mampu mencegah masyarakat pada umumnya, dan anak lainnya pada khususnya untuk tidak melakukan kejahatan.

Berdasarkan hasil penelitian yang telah dilakukan oleh penulis, hakim Pengadilan Negeri Purwokerto cenderung menganut teori tujuan pemidanaan utilitarian, hal ini dapat dilihat dari produk yang dihasilkan berupa putusan pengadilan yang memidana jauh lebih ringan dibandingkan dengan ketentuan yang terdapat dalam KUHP. Pidana bukanlah sekedar untuk melakukan pembalasan, tetapi mempunyai tujuan-tujuan tertentu yang bermanfaat bagi pelaku untuk bekal kehidupannya di masa mendatang. Namun, ketika hakim menjatuhkan sanksi pidana penjara masa pendek terhadap anak, yang hanya beberapa bulan atau bahkan beberapa hari saja, apabila dikaitkan dengan prinsip kemasyarakatan dan pembinaan narapidana maka ada kecenderungan pidana penjara yang pendek itu menjadi tidak efektif, mengingat bahwa pemasyarakatan adalah suatu proses pembinaan narapidana yang disebut "therapeutics process", maka membina narapidana sama dengan menyembuhkan seseorang yang sementara tersesat hidupnya karena adanya kelemahankelemahan yang dimiliki, dalam usaha penyembuhan ini tentunya memerlukan waktu yang relatif panjang ${ }^{6}$ untuk dapat merasakan manfaat yang diperoleh dari hasil pembinaan yang ada dalam LPKA.

6 Krismiyarsi, Naniek Rahadjeng. "Efektivitas Penerapan Sanksi Pidana Penjara Terhadap Anak Nakal Di Pengadilan Negeri Semarang”. Jurnal Untagsmg. Vol. 4 No. 1 Edisi Tahun 2006. Semarang: Universitas 17 Agustus 1945. 
Selanjutnya mengenai efektivitas pidana penjara terhadap anak dilihat dari aspek perbaikan si pelaku, meskipun LPKA Kutoarjo telah berupaya memberikan pembinaan semaksimal mungkin, tidak ada jaminan pasti bahwa begitu keluar dari lembaga ini, anak binaan akan benar-benar menjadi pribadi yang baik dan tidak melakukan tindak pidana lagi. Pidana penjara justru dapat menimbulkan prisonisasi. Risiko terjadinya prisonisasi ini semakin bertambah besar mengingat sistem pembinaan di LPKA Kutoarjo tidak ada pemisahan tempat pembinaan berdasarkan usia, jenis tindak pidana, dan jangka waktu pembinaan yang sudah dilalui sebagaimana dengan apa yang diamanatkan oleh Pasal 12 ayat (1) Undang-Undang Nomor 12 Tahun 1995 tentang Pemasyarakatan.

Kemudian efektivitas pidana penjara dilihat dari hak-hak anak dalam Konvensi tentang HakHak Anak 1989 (Resolusi PBB Nomor 44/25 Tanggal 5 Desember 1989) yang telah diratifikasi berdasarkan Kepres RI Nomor 36 Tahun 1990 tentang Pengesahan Convention On The Rights of the Child (Konvensi tentang Hak-Hak Anak) yaitu:

a. Hak Terhadap Kelangsungan Hidup (Survival Rights)

Hak untuk memperoleh standar kesehatan tertinggi dan pearwatan yang sebaik-baiknya.

Berdasarkan pengakuan dari salah seorang Anak Didik Pemasyarakatan (andikpas) pada LPKA Kutoarjo, masalah tempat tidur dan makanan yang dikonsumsi sudah cukup layak. Setiap hari dilakukan kontrol kesehatan, namun tidak ada dokter khusus yang menangani masalah kesehatan anak. Terhadap andikpas yang sakit hanya diberikan obat-obatan seadanya oleh petugas. b. Hak Terhadap Perlindungan (Protection Rights)

Hak anak untuk mendapat perlindungan dari diskriminasi.

Berdasarkan keterangan dari Kepala LPKA Kutoarjo diperoleh informasi bahwa dalam pelaksanaannya, terhadap anak yang menjalani pidana penjara di LPKA Kutoarjo, semua mendapatkan perlakuan yang sama, baik yang recidivis maupun bukan, atau dari segi lainnya tidak ada perbedaan perlakuan satu sama lain. Semua Anak Didik LPKA Kutoarjo diikutsertakan dalam kegiatan sesuai minat dan bakatnya berdasarkan hasil assessment.

c. Hak Untuk Tumbuh Kembang (Development Rights)

Meliputi segala bentuk pendidikan baik formal maupun informal) dan hak untuk mencapai standar hidup yang layak bagi perkembangan anak.

Berdasarkan hasil penelitian diperoleh informasi bahwa, di LPKA Kutoarjo terdapat sekolah sebagaimana sekolah pada umumnya, hanya saja menggunakan kurikulum kejar paket yaitu paket A, B, dan C. Kemudian ada program pelatihan ketrampilan seperti sablon, pertanian, perikanan, peternakan, kerajinan, sandal batik, dan membatik yang disesuaikan dengan kebutuhan anak-anak binaan. Ada pula kegiatan-kegiatan keagamaan, olahraga, kesenian seperti karawitan dan band, maupun terkait dengan wawasan kebangsaan. Intinya, pembinaan di LPKA Kutoarjo berfokus pada pembinaan kemandirian agar mereka menjadi sosok yang lebih baik lagi setelah selesai menjalani masa pidana penjara.

d. Hak Untuk Berpartisipasi (Participation Rights)

Hak untuk menyatakan pendapat dalam segala hal yang mempengaruhi anak.

Pada saat menjalani masa pidananya di LPKA Kutoarjo menerapkan sistem perwalian, dimana anak dapat mencurahkan isi hatinya tentang masalah-masalah yang membebaninya dan wali sigap mendengarkan serta memberi solusi. 


\section{Faktor-Faktor Penghambat Efektivitas Penerapan Sanksi Pidana Penjara Terhadap Anak Yang Melakukan Tindak Pidana Di Wilayah Hukum Pengadilan Negeri Purwokerto}

Faktor-faktor yang menghambat efektivitas penerapan sanksi pidana penjara terhadap anak yang melakukan tindak pidana di wilayah hukum Pengadilan Negeri Purwokerto dilihat dari teori yang dikemukakan oleh Soerjono Soekanto dalam teori efektivitas hukum, yaitu: ${ }^{7}$

a. Faktor Hukum, yaitu Peraturan yang mengatur tentang penerapan sanksi pidana penjara terhadap anak yang melakukan tindak pidana.

Sesuai dengan amanat yang terkandung dalam UU SPPA, pemerintah diwajibkan untuk membuat 6 (enam) materi dalam bentuk Peraturan Pemerintah dan 2 (dua) materi dalam bentuk Peraturan Presiden. Tetapi sampai saat ini peraturan pendukung tersebut masih belum semua tersedia.

b. Faktor Penegak Hukum, yaitu ketrampilan profesional dan mental penegak hukum dalam menangani perkara anak.

Para penegak hukum di wilayah hukum Pengadilan Negeri Purwokerto masih menggunakan pola pikir tradisional, khususnya hakim dalam menerapkan sanksi pidana penjara terhadap anak dikarenakan anak tersebut dari awal sudah dilakukan penahanan baik dari pihak kejaksaan maupun kepolisian. Seharusnya hakim mempunyai wewenang dan kebebasan tersendiri dalam menjatuhkan sanksi pidana terhadap anak, terlebih lagi hal itu dilakukan demi kepentingan terbaik bagi anak.

c. Faktor Sarana dan Fasilitas Pendukung, yaitu prasarana atau fasilitas yang digunakan sebagai alat untuk mencapai efektivitas penerapan sanksi pidana penjara terhadap anak.

Pada wilayah hukum Pengadilan Negeri Purwokerto belum terdapat LPAS, LPKS, dan RPKA sebagai pengganti tempat Penahanan, Pembinaan dan Lapas Anak. Sebagian besar Anak yang ditangkap kemudian dititipkan ke Rutan atau Lapas, yang justru bertentangan dengan perintah UU SPPA dan melanggar hak Anak. Akibatnya, tidak terhindarkan kondisi Anak yang ditahan sejak penyidikan sampai dengan putusan pengadilan karena tidak adanya lembaga yang diamanatkan oleh UU SPPA tersebut.

d. Faktor Masyarakat, yaitu lingkungan dimana anak yang keluar dari penjara melanjutkan kehidupa nnya

Berdasarkan hasil wawancara dengan masyarakat yang tinggal di lingkungan sekitar rumah dari anak yang pernah menjalani masa pidana penjara di LPKA Kutoarjo, masyarakat masih memberikan stigma negatif terhadap anak yang telah menjalani pidana penjara dengan di cap sebagai anak yang "jahat" dan memiliki pribadi yang buruk sehingga masyarakat menolak kehadirannya sebab masyarakat khawatir kalau anak tersebut akan mengulangi kejahatan dan akan memberikan pelajaran yang tidak baik terhadap anak-anak yang lain.

e. Faktor Kebudayaan, yaitu suatu garis pokok tentang perikelakuan yang menetapkan peraturan mengenai apa yang harus dilakukan dan apa yang dilarang.

Dilihat dari sudut pandang kebudayaan masyarakat Jawa, khususnya di wilayah Purwokerto, penerapan sanksi pidana penjara terhadap anak kurang tepat. Karena apabila anak dipenjara, maka akan terpisah dari kelurganya sehingga akan berdampak pada gangguan hubungan keluarga seperti terlalu singkatnya dalam memberikan pendidikan pengarahan bimbingan positif dari orang tua terhadap anak. Jadi, dengan memasukkan anak ke dalam penjara itu bertentangan dengan budaya membimbing anak, sehingga lebih baik dikembalikan ke orang tua, karena orang tua dan keluarga merupakan pembimbing terbaik bagi anak.

Soerjono Soekanto, 2008, Faktor-Faktor yang Mempengarubi Penegakan Hukum, Jakarta: PT. Raja Grafindo Persada, hlm. 8. 


\section{PENUTUP}

Penerapan sanksi pidana penjara terhadap anak yang melakukan tindak pidana di wilayah hukum Pengadilan Negeri Purwokerto tidak efektif. Hal ini dikarenakan aparat penegak hukum masih berpikir tradisional, bahwa alasan anak dijatuhi pidana penjara adalah karena anak tersebut sudah ditahan, tidak memperhatikan kepentingan terbaik bagi anak. Di sisi lain, angka kriminalitas dari tahun ke tahun cenderung mengalami peningkatan, sehingga pidana penjara belum mampu mencegah warga masyarakat untuk melakukan kejahatan. Pidana penjara juga menimbulkan prisonisasi. Hak-hak anak yang diperoleh selama menjalani masa pembinaan di LPKA Kutoarjo juga belum sepenuhnya terpenuhi, terutama masalah kesehatan. Faktor-faktor penghambat efektivitas penerapan sanksi pidana penjara terhadap anak yang melakukan tindak pidana di wilayah hukum Pengadilan Negeri Purwokerto yaitu faktor hukum; faktor penegak hukum; faktor sarana atau fasilitas pendukung; faktor masyarakat; dan faktor kebudayaan. Efektivitas penerapan sanksi pidana penjara terhadap anak hanya dapat terlaksana dengan baik, manakala hukum dijunjung tinggi dan moralitas penegak hukumnya serta masyarakat yang mendukung ke arah itu.

\section{REFERENCES}

Andesgur, Ivnaini Analisa Kebijakan Hukum Lingkungan dalam Pengelolaan Pestisida, Jurnal Bestuur Vol.VII, Issue.2, December, 2019.

Amirudin dan Ashikin, Zainal. 1990. Pengantar Metode Penelitian Hukum, Jakarta: Ghalia Indonesia. Handayani, I Gusti Ayu Ketut Rachmi, Lego Karjoko, dan Abdul Kadir Jaelani, Model Pelaksanaan Putusan Mahkamah Konstitusi yang Eksekutabilitas Dalam Pengujian Peraturan PerundangUndangan di Indonesia, Jurnal Bestuur Vol.VII, Issue.1, Agustus, 2019.

Krismiyarsi. Rahadjeng, Naniek. "Efektivitas Penerapan Sanksi Pidana Penjara Terhadap Anak Nakal Di Pengadilan Negeri Semarang". Jurnal Untagsmg. Vol. 4 No. 1 Edisi Tahun 2006. Semarang: Universitas 17 Agustus 1945.

Lego Karjoko, Zaidah Nur Rosidah, I Gusti Ayu Ketut Rahmi Handayani, "Refleksi Paradigma Ilmu Pengetahuan Bagi Pembangunan Hukum Pengadaan Tanah", Jurnal Bestuur, Volume 7, Nomor 1 Tahun 2019.

I Gusti Ayu Ketut Rahmi Handayani, Lego Karjoko, Abdul Kadir Jaelani, "Model Pelaksanaan Putusan Mahkamah Konstitusi yang Eksekutabilitas Dalam Pengujian Peraturan PerundangUndangan di Indonesia", Jurnal Bestuur, Volume 7, Nomor 1 Tahun 2019.

Ivnaini Andesgur, "Analisa Kebijakan Hukum Lingkungan dalam Pengelolaan Pestisida", Jurnal Bestuur, Volume 7, Nomor 2 Tahun 2019.

Udiyo Basuki, Abdul Kadir Jaelani, "Problematika Pelaksanaan Putusan Mahkamah Konstitusi Nomor 100/PUU-XI/2013 Dalam Mendudukkan Pancasila Sebagai Dasar Negara”, Wacana Hukum, Vol. 24, Nomor 2 Tahun 2019.

Kurniawan. Alfianto, Riza. “Asas Ultimum Remedium Dalam Pemidanaan Anak Nakal”. Yuridika. Vol 23, No 1. Edisi Tahun 2008. Penerbit: Yuridika.

Muryani, Eni Sinergisitas Penegakan Hukum Pada Kasus Pertambangan Emas Tanpa Izin di Kabupaten Banyumas, Jawa Tengah, Jurnal Bestuur Vol.VII, Issue.2, December, 2019

Moeljatno. 1987. Asas-asas Hukum Pidana. Jakarta: Bina Aksara.

Pratiwi, Ayu Dian \& Pius Triwahyudi, Jaminan Perlindungan yang Berkeadilan bagi Tenaga Kerja

Difabel Akibat Kecelakaan Kerja, Jurnal Bestuur Vol.VII, Issue.2, December, 2019.

Prinst, Darwan. 2003. Hukum Anak Indonesia. Bandung: PT. Citra Aditya Bakti.

Soekanto, Soerjono. 2008. Faktor-Faktor yang Mempengarubi Penegakan Hukum. Jakarta: PT. Raja Grafindo Persada.

Wadong. Hasan, Maulana. 2000. Advokasi dan Hukum Perlindungan Anak. Jakarta: Grasindo. 
Wulandari, Febry \& Waluyo, Efektivitas Pemanfaatan Dana bagi Hasil Cukai Hasil Tembakau dalam Bidang Kesehatan di Kota Surakarta Tahun 2018, Jurnal Bestuur Vol.VII, Issue.1, Agustus, 2019

Lego Karjoko, Zaidah Nur Rosidah, I Gusti Ayu Ketut Rahmi Handayani, "Refleksi Paradigma Ilmu Pengetahuan Bagi Pembangunan Hukum Pengadaan Tanah”, Jurnal Bestuur, Volume 7, Nomor 1 Tahun 2019.

I Gusti Ayu Ketut Rahmi Handayani, Lego Karjoko, Abdul Kadir Jaelani, “Model Pelaksanaan Putusan Mahkamah Konstitusi yang Eksekutabilitas Dalam Pengujian Peraturan PerundangUndangan di Indonesia", Jurnal Bestuur, Volume 7, Nomor 1 Tahun 2019.

Ivnaini Andesgur, "Analisa Kebijakan Hukum Lingkungan dalam Pengelolaan Pestisida", Jurnal Bestuur, Volume 7, Nomor 2 Tahun 2019.

Udiyo Basuki, Abdul Kadir Jaelani, "Problematika Pelaksanaan Putusan Mahkamah Konstitusi Nomor 100/PUU-XI/2013 Dalam Mendudukkan Pancasila Sebagai Dasar Negara”, Wacana Hukum, Vol. 24, Nomor 2 Tahun 2019. 